\title{
Landscape heterogeneity drives contrasting concentration-discharge relationships in shale headwater catchments
}

\author{
E. M. Herndon ${ }^{1, a}$, A. L. Dere ${ }^{1, b}$, P. L. Sullivan ${ }^{1, c}$, D. Norris ${ }^{2}$, B. Reynolds ${ }^{2}$, and S. L. Brantley ${ }^{1}$ \\ ${ }^{1}$ Department of Geosciences, The Pennsylvania State University, University Park, PA 16802, USA \\ ${ }^{2}$ Centre for Ecology and Hydrology, Bangor, Gwynedd, LL57 2UW, UK \\ a currently at: Department of Geology, Kent State University, Kent, OH 44242, USA \\ b currently at: Department of Geography/Geology, University of Nebraska at Omaha, Omaha, NE 68182, USA \\ ${ }^{\mathrm{c}}$ currently at: Department of Geography, The University of Kansas, Lawrence, KS 66045, USA
}

Correspondence to: E. M. Herndon (eherndo1@kent.edu)

Received: 7 November 2014 - Published in Hydrol. Earth Syst. Sci. Discuss.: 8 January 2015

Revised: 7 July 2015 - Accepted: 11 July 2015 - Published: 3 August 2015

\begin{abstract}
Solute concentrations in stream water vary with discharge in patterns that record complex feedbacks between hydrologic and biogeochemical processes. In a comparison of three shale-underlain headwater catchments located in Pennsylvania, USA (the forested Shale Hills Critical Zone Observatory), and Wales, UK (the peatland-dominated Upper Hafren and forest-dominated Upper Hore catchments in the Plynlimon forest), dissimilar concentration-discharge $(C-Q)$ behaviors are best explained by contrasting landscape distributions of soil solution chemistry - especially dissolved organic carbon (DOC) - that have been established by patterns of vegetation and soil organic matter (SOM). Specifically, elements that are concentrated in organic-rich soils due to biotic cycling (Mn, Ca, K) or that form strong complexes with $\mathrm{DOC}(\mathrm{Fe}, \mathrm{Al})$ are spatially heterogeneous in pore waters because organic matter is heterogeneously distributed across the catchments. These solutes exhibit nonchemostatic behavior in the streams, and solute concentrations either decrease (Shale Hills) or increase (Plynlimon) with increasing discharge. In contrast, solutes that are concentrated in soil minerals and form only weak complexes with $\mathrm{DOC}(\mathrm{Na}, \mathrm{Mg}, \mathrm{Si})$ are spatially homogeneous in pore waters across each catchment. These solutes are chemostatic in that their stream concentrations vary little with stream discharge, likely because these solutes are released quickly from exchange sites in the soils during rainfall events. Furthermore, concentration-discharge relationships of non-chemostatic solutes changed following tree harvest in
\end{abstract}

the Upper Hore catchment in Plynlimon, while no changes were observed for chemostatic solutes, underscoring the role of vegetation in regulating the concentrations of certain elements in the stream. These results indicate that differences in the hydrologic connectivity of organic-rich soils to the stream drive differences in concentration behavior between catchments. As such, in catchments where SOM is dominantly in lowlands (e.g., Shale Hills), we infer that nonchemostatic elements associated with organic matter are released to the stream early during rainfall events, whereas in catchments where SOM is dominantly in uplands (e.g., Plynlimon), these non-chemostatic elements are released later during rainfall events. The distribution of SOM across the landscape is thus a key component for predictive models of solute transport in headwater catchments.

\section{Introduction}

Streams are regularly monitored to evaluate watershed geochemistry, ecosystem health, and suitability for human use. However, streams integrate hydrologic and biogeochemical processes over varied spatial and temporal scales, making it difficult to determine both the sources and flow paths of solutes. While many researchers examine short-term to long-term element variability in stream water, it has remained difficult to derive generalized models quantifying so- 
lute concentration-discharge behavior (Fisher et al., 2004; Sivapalan, 2005; Zimmer et al., 2012). Flow paths may dictate stream chemistry by controlling fluid residence times and chemical equilibration of flowing water with soil minerals within catchments (Maher, 2011). Therefore, it is necessary to understand how heterogeneous flow paths through distinct chemical sources within a catchment influence observed solute concentration patterns within streams.

When the discharge of a stream $(Q)$ increases, concentrations of solutes $(C)$ can either increase (enrichment behavior), decrease (dilution behavior), or, perhaps most paradoxically, change very little (chemostasis) (Kirchner, 2003; Godsey et al., 2009; Clow and Mast, 2010). Dilution can result during rainfall events as water stored in a catchment is diluted by less concentrated meteoric water. Enrichment can result if a more concentrated source (e.g., groundwater) mixes with stream water during large rainfall events (Johnson et al., 1969). In contrast, chemostasis cannot be explained by the simple mixing of multiple sources and therefore has been attributed to processes such as chemical reactions with the solid phase along the pathway of water flow (Godsey et al., 2009). Although changing flow paths through soil horizons may explain differences in solute response to discharge along hillslope transects (e.g., Bishop et al., 2004), solutes often show different types of behavior in different streams due to landscape heterogeneity, and a unifying explanation for $C-Q$ behavior has remained elusive.

Behavior differences amongst individual solutes in the stream have been linked to variability in solute concentrations within a catchment; in other words, discrete zones of element mobilization within soils and sediments can lead to pulses of solute transport into a stream (McClain et al., 2003; Andrews et al., 2011). This effect is furthermore affected by changes in hydrologic connectivity, defined as the water-mediated transfer of constituents between water sources (Pringle, 2001), within a catchment during rainfall events. Stream chemistry can vary during storm events as dominant water inputs to the stream shift from groundwater and riparian zones during base flow to hillslope runoff at high flow as pore waters stored in upland soils become increasingly connected to the stream (McGlynn and McDonnell, 2003a). Throughout this paper, groundwater is defined as water that is stored in catchment soils and bedrock below the water table, and pore water is defined as water that is present in the pores of unsaturated soil in the vadose zone. Upland soils become hydrologically connected to the stream when soil layers become water-saturated, promoting downslope flow within the unsaturated zone. As a result, concentrations of solutes that are stored preferentially in the riparian zone, e.g., dissolved organic carbon (DOC) released from soil organic matter (SOM), peak in the stream prior to discharge or with rising discharge during storm events (McGlynn and McDonnell, 2003b; Hood et al., 2006). Variability in organic carbon dynamics across different landscape units can subsequently control metal export from headwater catchments and downstream hydrochemistry (Köhler et al., 2014).

Many previous studies examine single catchments and/or catchments that were developed on multiple lithologies (e.g., Johnson et al., 1969; Krám et al., 1997; Brown et al., 1999; Likens and Buso, 2006; Godsey et al., 2009), making the interpretation of solute behaviors difficult at best. When monolithologic catchments are compared, insights into other factors that influence the response of stream chemistry to discharge (e.g., biota, climatic) can be developed. To elucidate controls on stream chemistry not primarily driven by lithology, we examined $C-Q$ relationships in three shaleunderlain headwater streams with extensive hydrogeochemical data sets. Although these catchments are underlain by chemically similar shales, their soils have developed distinct and contrasting distributions of SOM across each landscape; i.e., organic-rich soils are predominantly in lowlands and swales in the Shale Hills Critical Zone Observatory but in upland peat regions of the Upper Hore and Upper Hafren catchments in the Plynlimon forest. Additionally, we investigate how $C-Q$ patterns change following tree harvest in the forested Upper Hore. For these catchments, variations in stream chemistry with flow elucidate non-lithological factors that control solute transport to streams, yielding a paradigm that should help explain other catchments.

\section{Methods}

Water chemistry was compared for three sites: (1) the Susquehanna Shale Hills Critical Zone Observatory (Shale Hills) in central Pennsylvania, USA, and (2) the Upper Hore and (3) Upper Hafren subcatchments in the Plynlimon experimental forest in Wales, UK (Fig. 1). The Shale Hills and Plynlimon forests are underlain almost exclusively by Fe-rich, organic-poor, Silurian-aged shale formations that are stratigraphically equivalent. Although these headwater catchments vary by size and location, their similar lithologies and extensive hydrogeochemical characterization (e.g., Kirby et al., 1991; Neal et al., 1997, 2011, 2013a, b; Shand et al., 2005a, b; Jin et al., 2010; Brantley et al., 2013a-j; Dere et al., 2013) allow for development of a unifying theory on factors controlling concentration-discharge behavior.

\subsection{Susquehanna Shale Hills Critical Zone Observatory}

Shale Hills is an 8 ha forested headwater catchment nested within the larger Susquehanna River basin in Pennsylvania, USA. Shale Hills contains primarily Inceptisol soils developed from shale residuum or colluvium of the Rose Hill Formation, which is dominantly comprised of clay minerals and quartz (Lin et al., 2006; Jin et al., 2010). Small areas of Ultisols are present near the stream (Lin et al., 2006). The regional mean annual temperature (MAT) is $10^{\circ} \mathrm{C}$, and pre- 


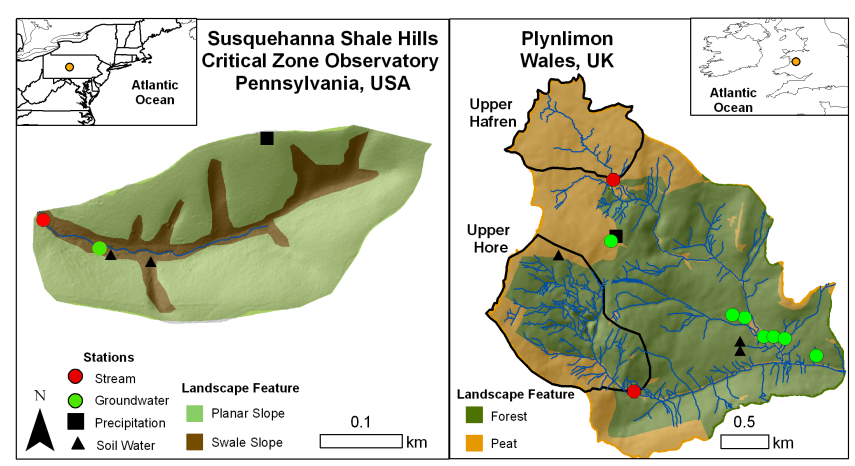

Figure 1. Map views of the Susquehanna Shale Hill Critical Zone Observatory (Shale Hills, PA, USA; left) and Plynlimon (Wales, UK; right) catchments. Symbols mark locations of precipitation (black square), stream water (red circle), pore water (black triangle), and groundwater (green circle) samplers. Shading delineates major landscape features that are organic rich or organic poor in each catchment: swale (brown) versus planar (light green) slopes at Shale Hills or peat ( $\tan )$ versus forested (dark green) regions at Plynlimon. Notably, the most organic-rich soils are in lowlands in Shale Hills but uplands in Plynlimon; consequently, inputs from organic-rich soils dominate stream flow under low-flow conditions in Shale Hills but high-flow conditions in Plynlimon.

cipitation ( $\mathrm{MAP}=105 \pm 17 \mathrm{~cm} \mathrm{yr}^{-1}$ ) is acidic (e.g., $\mathrm{pH}$ averaged $4.5 \pm 0.2$ for US National Atmospheric Deposition Program (NADP) sites PA15 and PA42 during 2000-2011). Vegetation is dominated by deciduous oaks and hickories, and the elevation ranges from $256 \mathrm{~m}$ at the catchment outlet to $310 \mathrm{~m}$ on the ridge. Hillslopes are characterized as either "planar" (mildly convex-upward slopes with shallow soils that grade to concave-upward slopes toward valley floor) or "swale" (concave-upward depressions with deep soils and convergent water flow) (Lin et al., 2006) (Fig. 1). Water flows vertically through pores when soils are unsaturated, or downslope along horizon interfaces when rainfall events create transiently perched saturated water zones (Lin, 2006; Jin et al., 2011). Soils in swales are generally wetter than soils on planar hillslopes and remain hydrologically connected to the stream during dry periods, whereas water flow through planar hillslopes is negligible under dry conditions and increases with increasing precipitation (Lin et al., 2006; Qu and Duffy, 2007; Takagi and Lin, 2012). Soils in the swales also store more organic carbon than soils on planar hillslopes and act as sources of DOC transport into streams (Andrews et al., 2011) (Table 1).

Water samples from Shale Hills were collected approximately daily from the stream outlet (2008-2010) and biweekly from soil lysimeters (2006-2011) from March to early December each year (Table 2). Detailed methods and results of chemical analyses, including isotopic variation and concentrations of major ions and DOC, have been reported elsewhere (Jin et al., 2011; Andrews et al., 2011; Brantley et al., 2013a-j). Aluminum concentrations in the stream were
Table 1. Soil profile descriptions and associated soil organic carbon (SOC) (\% wt) and dissolved organic carbon (DOC) (mM) averages.

\begin{tabular}{|c|c|c|c|c|c|}
\hline Site & Category & Horizon & $\begin{array}{r}\text { Depth } \\
(\mathrm{cm})\end{array}$ & $\begin{array}{r}\mathrm{DOC} \\
(\mathrm{mM})\end{array}$ & $\begin{array}{l}\mathrm{SOC}^{\mathrm{b}} \\
(\% \mathrm{wt})\end{array}$ \\
\hline \multicolumn{6}{|l|}{ Shale Hills ${ }^{\mathrm{c}}$} \\
\hline \multirow[t]{4}{*}{ Planar, valley } & Mineral & A & $0-15$ & 0.69 & 4.7 \\
\hline & Mineral & $\mathrm{Bw}$ & $15-30$ & 0.54 & 1.6 \\
\hline & & $\mathrm{Bt}$ & $30-53$ & - & - \\
\hline & & $\mathrm{C}$ & $53-147$ & - & - \\
\hline \multirow[t]{4}{*}{ Swale, valley } & Organic & A & $0-11$ & 1.28 & 2.0 \\
\hline & Mineral & $\mathrm{Bw}$ & $11-38$ & 0.55 & 1.2 \\
\hline & & $\mathrm{BC}$ & $38-60$ & - & - \\
\hline & & $\mathrm{C}$ & $60-178$ & - & - \\
\hline \multicolumn{6}{|l|}{ Plynlimon $^{\mathrm{d}}$} \\
\hline Peat & Organic & $\mathrm{O}$ & $0-100+$ & 1.10 & $40-50$ \\
\hline \multirow[t]{4}{*}{ Peaty gley } & Organic & $\mathrm{O}$ & $0-22$ & 1.37 & 25 \\
\hline & Mineral & Eag & $22-37$ & 0.49 & $5-6$ \\
\hline & & Bs & $37-86$ & - & - \\
\hline & & $\mathrm{C}$ & $86-107$ & - & - \\
\hline \multirow[t]{4}{*}{ Stagnopodzol } & Organic & $\mathrm{O}$ & 0-19 & 1.12 & 46 \\
\hline & Mineral & Eag & 19-24 & 0.35 & 5 \\
\hline & & Bs & $24-51$ & - & - \\
\hline & & $\mathrm{C}$ & $51-89$ & - & - \\
\hline
\end{tabular}

${ }^{a}$ Category (organic or mineral) assigned to soil horizons in this paper; note that reported SOC and DOC values are averaged over all mineral horizons. ${ }^{b}$ Shale Hills SOC estimates from Jin et al. (2010) and Andrews (2011). ${ }^{c}$ Shale Hills soil descriptions from Lin (2006). Plynlimon soil descriptions from Rudeforth et al. (1984).

consistently below detection limits; thus, Al data were not examined for Shale Hills. Daily discharge rates were estimated from continuous discharge measurements integrated over $10 \mathrm{~min}$ intervals from the stream weir at the catchment's outlet (Duffy, 2012). Soil water was collected from suction lysimeters installed in the soil at $10 \mathrm{~cm}$ depth increments from 10 to $50 \mathrm{~cm}$ depth in the south planar valley floor (SPVF) and from 10 to $90 \mathrm{~cm}$ depth in the south swale valley floor (SSVF). The groundwater was sampled from a $2.8 \mathrm{~m}$ deep well located $80 \mathrm{~m}$ upstream from the weir. Major cation (2000-2011; NADP, 2011) and trace element concentrations (Herndon et al., 2015) have been reported for precipitation samples collected from NADP sites PA-15 and PA-42. Vegetation chemistry was previously determined for green leaf and leaf litter samples collected throughout summer and autumn seasons, respectively, in the Shale Hills catchment (Herndon et al., 2015).

\subsection{Plynlimon forest: Upper Hore and Upper Hafren catchments}

The Plynlimon forest is a 682 ha watershed located at the headwater of the River Severn, $20 \mathrm{~km}$ from the west coast of Wales (Reynolds et al., 1997). MAT is $7.2^{\circ} \mathrm{C}$ and MAP is $250 \pm 78 \mathrm{~cm}$ with an average $\mathrm{pH}$ of $4.98 \pm 0.01$. Vegetation is predominantly evergreen Sitka spruce (Picea sitchensis) with areas of heath, including Sphagnum and Juncus communities, dominating the uplands. Elevation in the Plynlimon forest ranges from 319 to $738 \mathrm{~m}$. 
Table 2. Element concentrations ( \pm standard error) in water (precipitation, soil pore water, stream water, groundwater) and vegetation (green leaves, leaf litter) averaged over all available data collected from the Susquehanna Shale Hills Critical Zone Observatory in Pennsylvania, USA, between 2006 and 2011.

\begin{tabular}{|c|c|c|c|c|c|c|c|c|c|}
\hline & $\mathrm{pH}$ & $\mathrm{Na}$ & K & $\mathrm{Mg}$ & $\mathrm{Ca}$ & $\mathrm{Si}$ & $\mathrm{Fe}$ & $\mathrm{Mn}$ & DOC \\
\hline & & \multicolumn{7}{|c|}{$\mu \mathrm{mol} \mathrm{L}^{-1}$} & $\mathrm{mmol} \mathrm{L}^{-1}$ \\
\hline Precipitation & 4.5 & 2.1 & 0.67 & 0.73 & 2.65 & - & 0.24 & 0.05 & $0.08^{*}$ \\
\hline$\pm \mathrm{SE}$ & 0.2 & 0.4 & 0.28 & 0.16 & 0.51 & - & 0.14 & 0.01 & 0.02 \\
\hline \multicolumn{10}{|l|}{ Soil pore water } \\
\hline SPVF, A horizon & 4.5 & 29 & 34 & 62 & 142 & 123 & 0.61 & 0.38 & 0.69 \\
\hline$\pm \mathrm{SE}$ & 0.2 & 3 & 3 & 10 & 26 & 5 & 0.15 & 0.06 & 0.06 \\
\hline SPVF, B horizon & 4.7 & 34 & 29 & 89 & 146 & 125 & 0.25 & 0.44 & 0.54 \\
\hline$\pm \mathrm{SE}$ & $<0.1$ & 2 & 1 & 8 & 15 & 3 & 0.02 & 0.05 & 0.04 \\
\hline SSVF, A horizon & 3.9 & 21 & 88 & 39 & 72 & 112 & 1.7 & 6.8 & 1.28 \\
\hline$\pm \mathrm{SE}$ & 0.1 & 3 & 14 & 5 & 11 & 11 & 0.26 & 1.9 & 0.33 \\
\hline SSVF, B horizon & 4.4 & 28 & 29 & 79 & 35 & 126 & 0.21 & 1.3 & 0.55 \\
\hline$\pm \mathrm{SE}$ & $<0.1$ & 1 & 1 & 2 & 1 & 2 & 0.03 & 0.1 & 0.03 \\
\hline Average, all soils & & 28 & 45 & 68 & 99 & 121 & 0.69 & 2.2 & 0.77 \\
\hline $\begin{array}{l}\text { Relative standard deviation } \\
(\text { RSD) }(\%) \text {, all soils }\end{array}$ & & 19 & 64 & 33 & 55 & 5 & 100 & 140 & 46 \\
\hline \multicolumn{10}{|l|}{ Stream water } \\
\hline Low flow & 6.3 & 39 & 50 & 162 & 450 & 108 & 14 & 5.2 & 0.81 \\
\hline$\pm \mathrm{SE}$ & $<0.1$ & $<1$ & 1 & 3 & 10 & 1 & 2 & 0.7 & 0.06 \\
\hline Moderate flow & 5.7 & 32 & 31 & 122 & 240 & 101 & 1.9 & 1.1 & 0.45 \\
\hline$\pm \mathrm{SE}$ & 0.1 & 1 & $<1$ & 3 & 7 & 1 & 0.4 & 0.2 & 0.03 \\
\hline High flow & 5.9 & 26 & 29 & 96 & 163 & 99 & 0.53 & 0.33 & 0.42 \\
\hline$\pm \mathrm{SE}$ & 0.1 & $<1$ & $<1$ & 2 & 6 & 1 & 0.02 & 0.03 & 0.03 \\
\hline Groundwater & - & 145 & 24 & 404 & 758 & 124 & 0.14 & 2.9 & 0.20 \\
\hline$\pm \mathrm{SE}$ & - & 6 & $<1$ & 13 & 27 & 1 & 0.08 & 0.2 & 0.05 \\
\hline \multirow[t]{2}{*}{ Vegetation } & & $\mathrm{Na}$ & K & $\mathrm{Mg}$ & $\mathrm{Ca}$ & $\mathrm{Si}$ & $\mathrm{Fe}$ & $\mathrm{Mn}$ & \\
\hline & \multicolumn{9}{|c|}{$\mu \mathrm{mol} \mathrm{g}^{-1}$} \\
\hline Leaf litter & & NA & 69 & 59 & 263 & $\mathrm{n} / \mathrm{a}$ & $\mathrm{n} / \mathrm{a}$ & 49 & \\
\hline$\pm \mathrm{SE}$ & & & 6 & 3 & 15 & & & 3 & \\
\hline Green leaves & & 1.1 & 221 & 69 & 186 & & 0.99 & 42 & \\
\hline$\pm \mathrm{SE}$ & & 0.2 & 15 & 7 & 18 & & 0.06 & 4 & \\
\hline
\end{tabular}

*Andrews et al. (2011); NA is not available.

We focus here on two adjacent headwater catchments within the Plynlimon watershed: the Upper Hore and the Upper Hafren (Fig. 1). The Upper Hore (162 ha) is predominantly forested with periodically saturated, organic-rich Stagnopodzol soils and uplands that are dominated by grass and saturated peat soils (Kirby et al., 1991). In contrast, the Upper Hafren (122 ha) is dominated by heath and peat soils, with waterlogged and organic-rich peaty gley soils located in riparian areas (Kirby et al., 1991). Generally, the main flow paths in both catchments are approximately orthogonal to the valley direction, with highly fractured shallow bedrock providing an important pathway and storage for water throughout the catchments, especially under base flow conditions (Haria and Shand, 2004; Shand et al., 2005a, b;
Shand et al., 2007). Shallow and deeper groundwater appear to be poorly connected but some mixing does occur (Haria and Shand, 2004; Shand et al., 2005b; Shand et al., 2007). Flow in organic horizons, however, tends to be largely lateral rather than vertical, providing minimal water-rock interaction in peat-dominated portions of the catchment and increasing contribution to streams during high-flow conditions (Shand et al., 2009).

Stream chemistry data for the Upper Hore and Upper Hafren catchments were collected throughout the year for all years between 1983 and 2005, and 1990 and 2010, respectively (Neal et al., 2013a, b). Due to extensive tree-cutting in the Upper Hore in 2005, data collected from 2005 to 2010 were evaluated separately to examine the influence of tree 
removal on $C-Q$ behavior. Stream discharge was measured every $15 \mathrm{~min}$ at weirs in both catchments and weekly stream grab samples were analyzed for major and trace ions. Likewise, bulk precipitation was collected weekly at the Carreg Wen meteorological station located between the Upper Hore and Upper Hafren catchments (Reynolds et al., 1997). Precipitation chemistry was influenced by seawater inputs, which varied with wind direction and season (Reynolds et al., 1987). Groundwater chemistry was estimated as average concentrations of solutes in seven shallow $(<3 \mathrm{~m})$ wells located within the Plynlimon forest near the two catchments (Fig. 1). Wells were sampled weekly from 1994 to 1999 (Neal et al., 1997) (Supplement Table S1). Average solute concentrations ( \pm standard error) were calculated for pore waters sampled from soils classified as peat, Stagnopodzol, or peaty gley throughout Plynlimon (Reynolds et al., 1987; Reynolds et al., 1988; Stevens et al., 1997; Shand et al., 2005b) (Table 3; Table S2).

\subsection{Stream flow regimes and concentration-discharge behaviors}

To analyze stream chemistry under different flow regimes, stream water discharge $\left(Q, \mathrm{~m}^{3} \mathrm{~d}^{-1}\right)$ was categorized as low flow (lower quartile of $Q$ ), moderate flow (interquartile range), or high flow (upper quartile) (Supplement Fig. S1). Perennial stream flow with little seasonal variation in discharge was observed in the Upper Hafren and Upper Hore catchments, and the distributions of $Q$ were positively skewed by intermittent storms. Stream flow at Shale Hills was intermittent and highly seasonal, with extended periods of no flow to low flow during summer months (especially July and August). Solute concentrations for each flow regime at each site were averaged over all collection dates (Tables 2 and 3).

Linear regressions were fit to $\log$-transformed $C-Q$ data for each solute $j\left(C_{j}\right)$ for each catchment stream. We included all available data for all years for Shale Hills (20082010), the Upper Hafren (1990-2010), and the pre-harvest Upper Hore (1983-2004). The data collected for the Upper Hore following harvest (2005-2010) were evaluated separately. The slope of this regression $\left(m_{j}\right)$ was used to identify solute behaviors as "chemostatic" or "non-chemostatic". When $m_{j}$ showed only minimal effects of dilution by meteoric water, i.e., $-0.1<m_{j}<0$, the solutes were defined as chemostatic (Godsey et al., 2009). In contrast, nonchemostatic elements were defined to exhibit dilution behavior when concentrations decreased with increasing $Q$ $\left(m_{j}<-0.1\right)$ or enrichment behavior when concentrations increased with increasing $Q\left(m_{j}>0\right)$. Linear regressions and associated statistical parameters were calculated in $\operatorname{Origin}(\mathrm{R})$ software (OriginLab).

To investigate sources of solutes mobilized to the stream, element ratios in the stream under different flow regimes were compared to element ratios in pore waters, precipita-
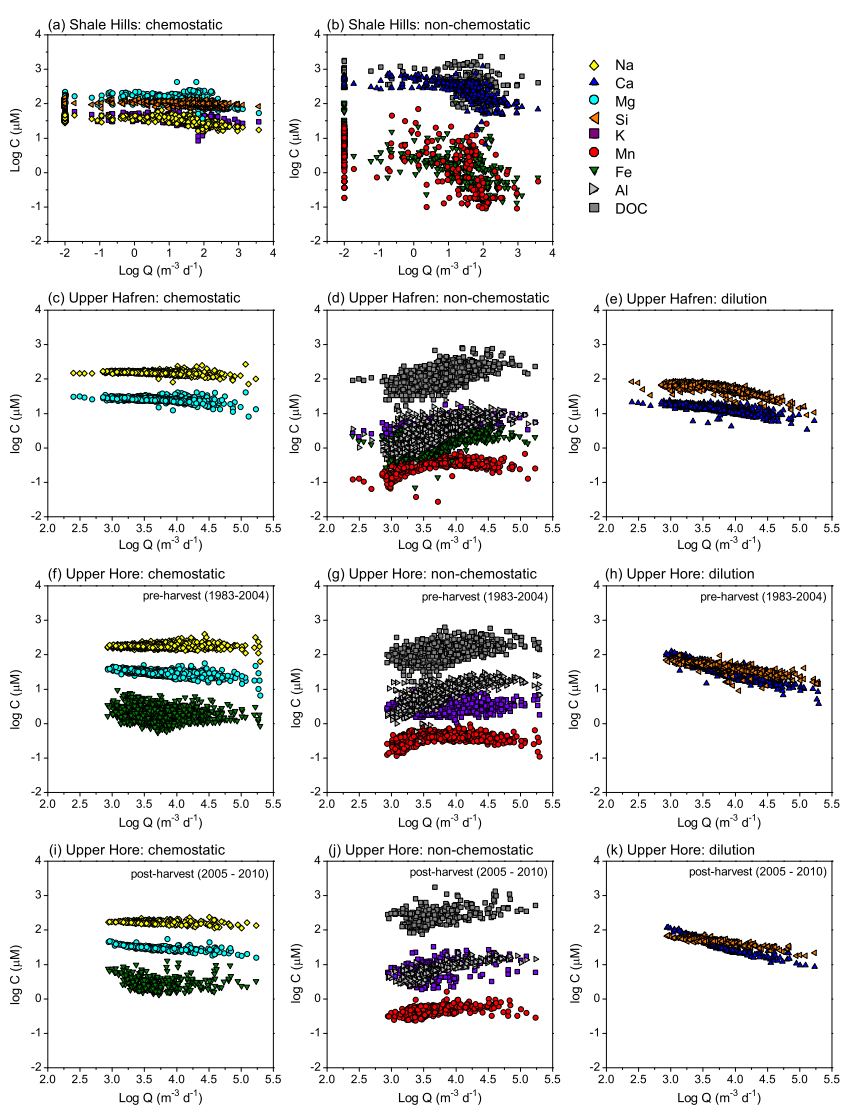

Figure 2. $\log -C$ (solute concentration) versus log- $Q$ (discharge) in the Shale Hills catchment (a, b) and two Plynlimon subcatchments, the Upper Hafren $(\mathbf{c}-\mathbf{e})$ and Upper Hore $(\mathbf{f}-\mathbf{h})$. Data from the postharvest period (2005-2010) in the Upper Hore are plotted in separate panels (i-k). For each catchment, the left panel shows elements that exhibit chemostatic behavior, the middle panel shows nonchemostatic elements that exhibit behavior similar to DOC (e.g., dilution at Shale Hills and enrichment at Plynlimon), and the right panel shows elements that exhibit dilution behavior.

tion, groundwater, and leaves (where available). Element ratios have been used in other studies to link river chemistry to end-member reservoirs (e.g., Gaillardet et al., 1999). Molar ratios of divalent cations $(\mathrm{Ca}: \mathrm{Mg})$ were compared to univalent cations $(\mathrm{K}: \mathrm{Na})$ in each reservoir to understand how elements exhibiting non-chemostasis $(\mathrm{Ca}, \mathrm{K})$ vary relative to chemostatic elements $(\mathrm{Mg}, \mathrm{Na})$. To further explore the association of certain non-chemostatic solutes with organic $\mathrm{C}$, molar ratios of $\mathrm{Mn}$ (a non-chemostatic element) to $\mathrm{Mg}$ were compared to DOC concentrations. Average DOC concentrations were used to define soil waters as organic rich or organic poor, as discussed in Sect. 3.2. In Shale Hills, green leaves were used to represent the most organic-rich end-member since pore waters could not be sampled from the thin $\mathrm{O}$ horizon. 
Table 3. Solute concentrations ( \pm standard error) averaged over all available data collected from the Upper Hore (pre-harvest: 1983-2005; post-harvest: 2005-2010) and Upper Hafren (1990-2010) catchments in the Plynlimon forest in Wales, UK.

\begin{tabular}{|c|c|c|c|c|c|c|c|c|c|c|}
\hline & \multirow[t]{2}{*}{$\mathrm{pH}$} & $\mathrm{Na}$ & $\mathrm{K}$ & $\mathrm{Mg}$ & $\mathrm{Ca}$ & $\mathrm{Si}$ & $\mathrm{Fe}$ & $\mathrm{Mn}$ & $\mathrm{Al}$ & \multirow{2}{*}{$\begin{array}{r}\text { DOC } \\
\mathrm{mmol} \mathrm{L}^{-1}\end{array}$} \\
\hline & & \multicolumn{8}{|c|}{$\mu \mathrm{mol} \mathrm{L} \mathrm{L}^{-1}$} & \\
\hline Precipitation & 4.98 & 69.6 & 2.60 & 8.52 & 6.89 & 2.63 & 0.19 & 0.03 & 0.66 & 0.045 \\
\hline$\pm \mathrm{SE}$ & 0.01 & 3 & 0.10 & 0.32 & 0.59 & 0.35 & 0.02 & $<0.01$ & 0.05 & 0.001 \\
\hline \multicolumn{11}{|l|}{ Soil pore water } \\
\hline Peat & 3.24 & 143 & 5.55 & 27.1 & 12.6 & 9.40 & 2.97 & 0.16 & 2.22 & 1.10 \\
\hline$\pm \mathrm{SE}$ & 0.10 & 4 & 0.54 & 1.2 & 0.5 & 0.38 & 0.15 & 0.02 & 0.20 & 0.45 \\
\hline Peaty gley organic & 3.56 & 239 & 29.7 & 30.0 & 8.32 & 47.6 & 9.29 & - & 26.6 & 1.37 \\
\hline$\pm \mathrm{SE}$ & 0.07 & 6 & 3.2 & 1.0 & 0.41 & 2.0 & 0.42 & - & 1.3 & 0.77 \\
\hline Peaty gley mineral & 4.16 & 220 & 10.2 & 26.7 & 5.32 & 57.1 & 12.2 & - & 55.9 & 0.49 \\
\hline$\pm \mathrm{SE}$ & 0.01 & 1 & 0.2 & 0.1 & 0.02 & 0.3 & 0.5 & - & 0.2 & 0.09 \\
\hline Stagnopodzol O & 3.82 & 165 & 25.7 & 29.8 & 22.7 & 18.9 & 4.25 & 0.27 & 8.00 & 1.12 \\
\hline$\pm \mathrm{SE}$ & 0.07 & 5 & 2.3 & 1.1 & 1.4 & 0.7 & 0.20 & 0.04 & 0.38 & 0.04 \\
\hline Stagnopodzol min & 4.12 & 159 & 7.91 & 19.9 & 11.7 & 33.7 & 0.96 & 0.47 & 19.9 & 0.35 \\
\hline$\pm \mathrm{SE}$ & 0.01 & $<1$ & 0.04 & $<0.1$ & 0.04 & 0.2 & 0.02 & 0.01 & 0.2 & $<0.01$ \\
\hline \multicolumn{11}{|l|}{ Upper Hore } \\
\hline Low flow & 6.98 & 177 & 3.06 & 36.1 & 78.3 & 63.0 & 2.59 & 0.32 & 3.56 & 0.10 \\
\hline$\pm \mathrm{SE}$ & 0.02 & 1 & 0.06 & 0.3 & 1.0 & 0.9 & 0.11 & 0.01 & 0.40 & $<0.01$ \\
\hline Moderate flow & 6.01 & 180 & 3.11 & 29.8 & 39.7 & 48.4 & 2.02 & 0.42 & 7.44 & 0.12 \\
\hline$\pm \mathrm{SE}$ & 0.02 & 1 & 0.05 & 0.1 & 0.5 & 0.3 & 0.04 & $<0.01$ & 0.12 & $<0.01$ \\
\hline High flow & 4.75 & 184 & 3.78 & 25.6 & 17.5 & 30.4 & 2.08 & 0.40 & 16.2 & 0.21 \\
\hline$\pm \mathrm{SE}$ & 0.02 & 3 & 0.11 & 0.5 & 0.4 & 0.5 & 0.07 & 0.01 & 0.3 & $<0.01$ \\
\hline Post-harvest, all flows & 5.96 & 169 & 8.9 & 30.2 & 41.3 & 45.0 & 3.33 & 0.51 & 7.9 & 0.31 \\
\hline$\pm \mathrm{SE}$ & 0.05 & 1 & 0.3 & 0.3 & 0.7 & 0.9 & 0.11 & 0.01 & 0.3 & 0.01 \\
\hline \multicolumn{11}{|l|}{ Upper Hafren } \\
\hline Low flow & 6.45 & 160 & 2.96 & 27.8 & 17.4 & 67.8 & 1.21 & 0.27 & 2.02 & 0.08 \\
\hline$\pm \mathrm{SE}$ & 0.02 & 1 & 0.06 & 0.2 & 0.1 & 1.0 & 0.06 & 0.01 & 0.18 & $<0.01$ \\
\hline Moderate flow & 5.79 & 153 & 3.52 & 26.0 & 13.8 & 57.7 & 1.74 & 0.38 & 3.51 & 0.13 \\
\hline$\pm \mathrm{SE}$ & 0.02 & $<1$ & 0.06 & 0.1 & 0.08 & 0.5 & 0.04 & $<0.01$ & 0.09 & $<0.01$ \\
\hline High flow & 4.85 & 142 & 5.04 & 22.8 & 10.1 & 34.5 & 2.68 & 0.34 & 7.44 & 0.24 \\
\hline$\pm \mathrm{SE}$ & 0.02 & 2 & 0.15 & 0.4 & 0.2 & 0.8 & 0.12 & 0.01 & 0.22 & 0.01 \\
\hline Groundwater & 5.26 & 227 & 8.7 & 79 & 94 & 86 & 5.9 & 2.54 & 1.86 & 0.032 \\
\hline$\pm \mathrm{SE}$ & 0.07 & 8 & 1.7 & 11 & 20 & 4 & 1.5 & 0.33 & 0.11 & 0.002 \\
\hline
\end{tabular}

\section{Results}

\subsection{Solute concentration-discharge patterns}

$\mathrm{Na}$ and $\mathrm{Mg}$ behaved near chemostatically in all catchments (Fig. 2; Table 4), while Si and K were only chemostatic at Shale Hills. A subset of non-chemostatic solutes exhibited similar trends to DOC; however, trends were opposite between Shale Hills and Plynlimon. Specifically, when $Q$ increased, concentrations of the non-chemostatic solutes $\mathrm{Ca}$, $\mathrm{Mn}, \mathrm{Fe}$, and DOC decreased at Shale Hills (i.e., dilution behavior; $m_{j}<-0.1$ ) while the non-chemostatic solutes Mn, $\mathrm{K}, \mathrm{Al}, \mathrm{Fe}$, and DOC increased at Plynlimon (i.e., enrichment behavior; $m_{j}>0$ ) (Fig. 2b; Table 4). Note that Fe exhibited enrichment $\left(m_{\mathrm{Fe}}=0.33 \pm 0.02\right)$ similar to DOC in the Up- per Hafren but was more consistent with chemostasis in the Upper Hore $\left(m_{\mathrm{Fe}}=-0.05 \pm 0.02\right)$. Additionally, $\mathrm{Si}$ and $\mathrm{Ca}$ showed dilution patterns at Plynlimon that contrasted with DOC.

In the Shale Hills stream, higher concentrations of stream solutes were observed during the dry summer season (June through September) relative to the wetter spring and autumn (Fig. S2). While concentrations of the chemostatic elements increased only slightly $(\sim 2 \times)$ during the summer, larger increases were observed for $\mathrm{Ca}(\sim 4 \times)$, DOC $(\sim 7 \times)$, and $\mathrm{Mn}$ and $\mathrm{Fe}(>100 \times)$. Increases in DOC, K, Fe, and $\mathrm{Mn}$ in the stream during summer were not consistent with increasing groundwater inputs because groundwater at Shale Hills is depleted in these elements relative to stream water at low flow (Table 2). In the Upper Hafren and Upper Hore streams, 
Table 4. Slopes of regression lines fit to $C-Q$ data $(\log \mathrm{C}=\mathrm{a}+\mathrm{m} \times \log Q)$ indicate chemostatic $^{\mathrm{a}}$, non-chemostatic ${ }^{\mathrm{b}}$, or dilution $^{\mathrm{c}}$ concentration-discharge patterns.

\begin{tabular}{|c|c|c|c|c|c|c|c|c|c|}
\hline & $\mathrm{Na}$ & $\mathrm{K}$ & $\mathrm{Ca}$ & $\mathrm{Mg}$ & $\mathrm{Si}$ & $\mathrm{Al}$ & $\mathrm{Fe}$ & Mn & DOC \\
\hline \multicolumn{10}{|c|}{ Shale Hills (2008-2010) } \\
\hline Slope $(m)$ & $-0.04^{\mathrm{a}}$ & $-0.07^{\mathrm{a}}$ & $-0.12^{\mathrm{b}}$ & $-0.05^{\mathrm{a}}$ & $-0.01^{\mathrm{a}}$ & - & $-0.30^{\mathrm{b}}$ & $-0.19^{b}$ & $-0.11^{b}$ \\
\hline SE & $<0.01$ & $<0.01$ & 0.01 & $<0.01$ & $<0.01$ & - & 0.01 & 0.02 & 0.02 \\
\hline$R^{2}$ & 0.32 & 0.56 & 0.43 & 0.30 & 0.09 & - & 0.58 & 0.24 & 0.14 \\
\hline \multicolumn{10}{|c|}{ Upper Hafren (1990-2010) } \\
\hline Slope $(m)$ & $-0.05^{\mathrm{a}}$ & $0.18^{\mathrm{b}}$ & $-0.20^{\mathrm{c}}$ & $-0.08^{\mathrm{a}}$ & $-0.26^{\mathrm{c}}$ & $0.58^{\mathrm{b}}$ & $0.33^{\mathrm{b}}$ & $0.10^{\mathrm{b}}$ & $0.42^{\mathrm{b}}$ \\
\hline SE & 0.00 & 0.01 & 0.00 & 0.00 & 0.01 & 0.02 & 0.02 & 0.01 & 0.02 \\
\hline$R^{2}$ & 0.20 & 0.19 & 0.64 & 0.27 & 0.67 & 0.53 & 0.26 & 0.08 & 0.37 \\
\hline \multicolumn{10}{|c|}{ Upper Hore (pre-harvest; 1983-2004) } \\
\hline Slope $(m)$ & $0.00^{\mathrm{a}}$ & $0.07^{b}$ & $-0.51^{\mathrm{c}}$ & $-0.12^{\mathrm{a}}$ & $-0.27^{\mathrm{c}}$ & $0.52^{\mathrm{b}}$ & $-0.05^{\mathrm{a}}$ & $0.05^{\mathrm{b}}$ & $0.26^{b}$ \\
\hline SE & 0.00 & 0.01 & 0.01 & 0.00 & 0.01 & 0.01 & 0.02 & 0.01 & 0.02 \\
\hline$R^{2}$ & 0.00 & 0.04 & 0.89 & 0.43 & 0.75 & 0.59 & 0.01 & 0.04 & 0.23 \\
\hline \multicolumn{10}{|c|}{ Upper Hore (post-harvest; 2005-2010) } \\
\hline Slope $(m)$ & $-0.04^{\mathrm{a}}$ & $0.26^{\mathrm{b}}$ & $-0.49^{\mathrm{c}}$ & $-0.11^{\mathrm{a}}$ & $-0.23^{\mathrm{c}}$ & $0.42^{\mathrm{b}}$ & $-0.04^{\mathrm{a}}$ & $0.12^{\mathrm{b}}$ & $0.25^{\mathrm{b}}$ \\
\hline SE & $<0.00$ & $<0.03$ & $<0.01$ & $<0.01$ & $<0.01$ & $<0.02$ & $<0.03$ & $<0.02$ & $<0.03$ \\
\hline$R^{2}$ & 0.12 & 0.18 & 0.90 & 0.50 & 0.83 & 0.68 & $<0.01$ & 0.16 & 0.21 \\
\hline
\end{tabular}

${ }^{1}$ Calculations exclude data where concentrations fell below the detection limit. ${ }^{2}$ All slopes are statistically different from zero $(p<0.001)$ except $\mathrm{Na}$ (pre-harvest) and Fe (post-harvest) in the Upper Hore.

chemostatic elements $\mathrm{Na}$ and $\mathrm{Mg}$, derived primarily from sea salts, showed no seasonality despite high seasonal variation in inputs from precipitation (Figs. S3-S5; Reynolds et al., 1987), as if precipitation-derived solutes were buffered in the catchment soil pore waters before entering the stream (Neal and Kirchner, 2000). In contrast, solutes exhibiting enrichment (K, Al, Mn, Fe, DOC) varied by season (Figs. S3 and S4).

In the Upper Hore where trees were harvested, solute concentrations and $C-Q$ slopes increased following tree harvest for solutes showing enrichment behavior. Specifically, stream concentrations of DOC, K, Mn, and Fe increased after 2005 (Table 3). Post-harvest $C-Q$ slopes for $m_{\mathrm{K}}(=0.26 \pm 0.03)$ and $m_{\mathrm{Mn}}(=0.12 \pm 0.02)$ increased relative to pre-harvest values $(0.07 \pm 0.01$ and $0.05 \pm 0.01$, respectively) (Fig. 2; Table 4). No effects of tree harvest on $C_{j}$ or $m_{j}$ were observed for chemostatic elements. Additionally, no changes in solute concentrations in the non-harvested Upper Hafren were observed over this time.

\subsection{Soil pore waters}

We examined the chemical composition of soil pore waters in order to investigate sources of solutes to the stream. Pore waters in each catchment were categorized into distinct chemical pools based on DOC concentrations (Table 2): "organicrich" waters were defined by average DOC $>1 \mathrm{mM}$, while all other waters were "organic poor". At Shale Hills, pore waters collected from the A horizon $(10 \mathrm{~cm})$ of the swale (SSVF) were organic rich $(1.28 \pm 0.33 \mathrm{mM}$ DOC) while all other pore waters were organic poor; i.e., the A horizon of $\operatorname{SPVF}(0.69 \pm 0.06 \mathrm{mM}$ DOC $)$ and the B horizons of SSVF and SPVF (> $10 \mathrm{~cm}$; averaged $0.55 \pm 0.04 \mathrm{mM}$ DOC) were organic poor. At Plynlimon, pore waters in organic horizons and peat soils $(1.2 \pm 0.2 \mathrm{mM}$ DOC) were organic rich relative to mineral horizons of Stagnopodzol and peaty gley soils $(0.42 \pm 0.07 \mathrm{mM}$ DOC $)$ soils.

At Shale Hills, concentrations of the non-chemostatic solutes $\mathrm{Mn}, \mathrm{Fe}$, and $\mathrm{Ca}$ showed evidence of DOC-related behavior. For example, $\mathrm{Mn}$ and $\mathrm{Fe}$ were positively correlated with DOC across all pore waters $\left(R^{2}>0.9\right)$ and were highest in the organic-rich waters $(6.8 \pm 1.9 \mu \mathrm{M}$ and $1.7 \pm 0.3 \mu \mathrm{M}$, respectively) (Table 2). Calcium concentrations were enriched in the A horizon $(72 \pm 11 \mu \mathrm{M})$ relative to the B horizon $(35 \pm 1 \mu \mathrm{M})$ in SSVF. Furthermore, Fe and Mn concentrations were spatially variable across pore waters (\% relative standard deviation $(\mathrm{RSD})=100$ and $140 \%$, respectively). In contrast, chemostatic solutes $\mathrm{Mg}(33 \%), \mathrm{Na}(19 \%)$, and $\mathrm{Si}(5 \%)$ were less variable. Thus, concentrations of nonchemostatic solutes were spatially heterogeneous in soil waters across the landscape while chemostatic solutes were distributed more homogeneously.

Like Shale Hills, concentrations of the chemostatic elements $\mathrm{Na}$ and $\mathrm{Mg}$ were spatially homogeneous in pore waters at Plynlimon amongst the different soils $(\mathrm{RSD}=23$ 

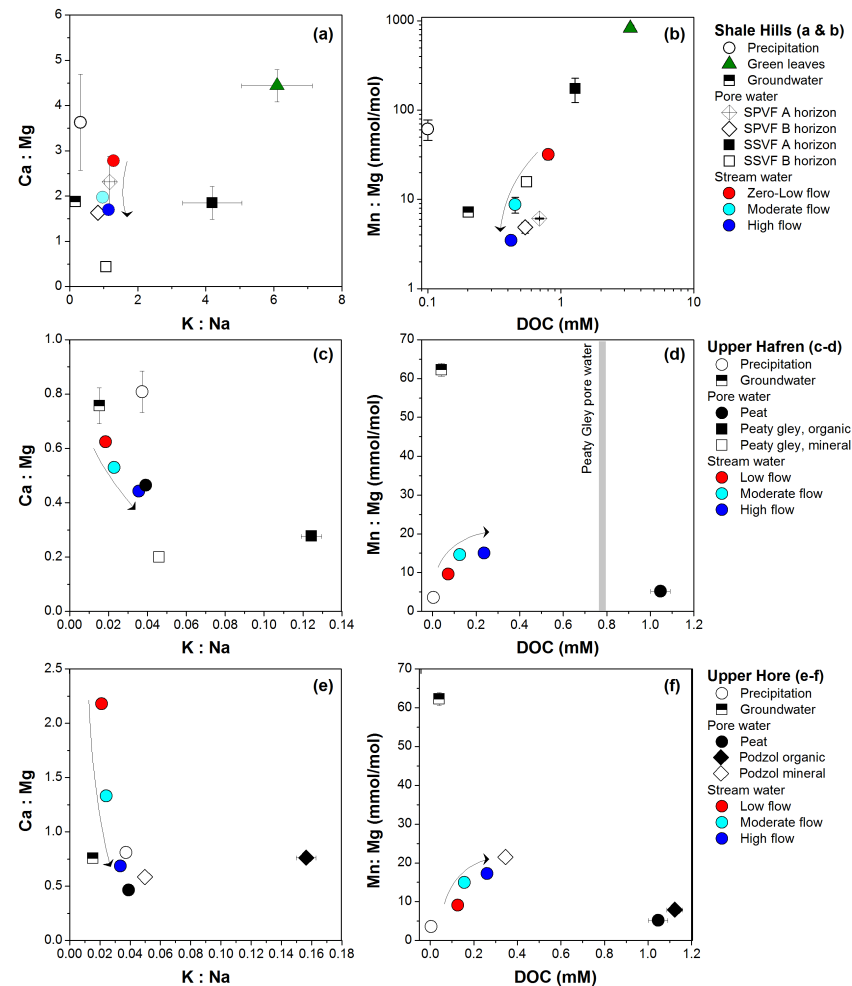

Figure 3. Molar ratios of major divalent $(\mathrm{Ca}: \mathrm{Mg})$ versus univalent $(\mathrm{K}: \mathrm{Na})$ cations are plotted on the left and the molar ratios of $\mathrm{Mn}$ (mmol) to $\mathrm{Mg}$ (mol) versus dissolved organic carbon $\left(\mathrm{mmol} \mathrm{L}^{-1}\right)$ are plotted on the right for solute source pools in the forested Shale Hills (a, b), peatland Upper Hafren $(\mathbf{c}, \mathbf{d})$, and predominately forested Upper Hore $(\mathbf{e}, \mathbf{f})$ catchments. Arrows indicate direction of increasing discharge for average stream chemistries. Values for total $\mathrm{C}\left(\sim 33 \mathrm{mmol} \mathrm{kg}^{-1}\right)$ and $\mathrm{K}: \mathrm{Na}(\sim 60)$ in leaves are divided by 10 to fit on plots (a) and (b). For soil pore water, filled symbols indicate organic-rich waters and open symbols indicate organic-poor waters.

and $15 \%$, respectively) (Table 3). Additional solutes chiefly derived from the atmosphere via precipitation $(\mathrm{K}, \mathrm{Ca})$ or through carbon fixation (DOC) were enriched in the organic horizons, while elements derived primarily from minerals ( $\mathrm{Si}, \mathrm{Fe}, \mathrm{Al}$, and $\mathrm{Mn}$ ) were enriched in mineral horizons. In contrast to Shale Hills, many of the non-chemostatic elements at Plynlimon were not correlated with DOC in soil pore waters.

Element ratios in stream water under low-, moderate, and high-flow regimes were compared to element ratios in pore waters, precipitation, and groundwater (Fig. 3). At Shale Hills, stream chemistry was most similar to pore waters from organic-rich soils and green leaves at low flow and approached values for pore waters from organic-poor soils at high flow. Ratios of $C_{\mathrm{Ca}}: C_{\mathrm{Mg}}$ and $C_{\mathrm{K}}: C_{\mathrm{Na}}$ decreased slightly $(<2 \times)$ with increasing discharge (Fig. 3a), while $C_{\mathrm{Mn}}: C_{\mathrm{Mg}}$ decreased by $10 \times$ (Fig. 3b). Stream water was more similar to soil pore waters than groundwater or precipitation under all flow regimes, documenting that flow through shallow soils and bedrock rather than deep groundwater sources dominated inputs to the stream. These trends further indicate a shift from inputs of organic-rich soil water to the stream at low-flow to organic-poor soil water at high flow.

In contrast to this behavior at Shale Hills, stream chemistries in the Upper Hore and Upper Hafren catchments were most similar to organic-poor sources (precipitation, groundwater) at low-flow and organic-rich sources (soil pore waters) at high flow (Fig. 3c-f; Fig. S6). Values of $C_{\mathrm{Mn}}$ : $C_{\mathrm{Mg}}, C_{\mathrm{DOC}}$, and $C_{\mathrm{K}}: C_{\mathrm{Na}}$ increased while $C_{\mathrm{Ca}}: C_{\mathrm{Mg}}$ decreased and converged towards the most organic-rich endmember in each system, either the peat (Upper Hafren) or peat and organic horizon pore waters (Upper Hore), with increasing discharge. Stream $C_{\mathrm{Ca}}: C_{\mathrm{Mg}}$ ratios were similar to groundwater at low flow in the Upper Hafren. The limited groundwater data that were available for Plynlimon indicate that groundwater was not chemically similar to stream water under any flow regime in the Upper Hore.

\subsection{Organic influence on concentration-discharge behavior}

Finally, we explored how chemical heterogeneity in soil pore waters influenced concentration-discharge relationships in the streams. Specifically, we evaluated solute heterogeneity due to redistribution by vegetation as the ratio of solute concentrations in "organic-rich" to "organic-poor" pore waters. As previously defined, these pore waters were collected from A versus B horizons at Shale Hills, and organic versus mineral soils in the Upper Hafren and Upper Hore. The slope of the concentration-discharge plot $\left(m_{j}\right)$ was used to define the magnitude of non-chemostatic behavior for each solute, i.e., the degree to which an element was diluted or enriched in the stream with increasing discharge.

At Shale Hills, elements concentrated in the organic-rich pore waters were diluted rapidly in the stream with increasing discharge, consistent with increasing inputs of water from mineral soils as the planar hillslope soils become saturated during storms (Qu and Duffy, 2007). This trend is documented in Fig. 4a where the concentration ratios for organicrich versus organic-poor soil waters were negatively correlated with respect to $m_{j}\left(R^{2}=0.90, p<0.001\right)$. According to these results, $\mathrm{Fe}$ and $\mathrm{Mn}$ were most concentrated in organicrich pore waters and most rapidly diluted in the stream, followed by DOC, Ca, and K. Chemostatic elements $\mathrm{Na}, \mathrm{Mg}$, and $\mathrm{Si}$ were not concentrated in organic-rich pore waters.

No significant correlation $(p>0.05)$ existed between organic to mineral pore-water ratios and $m_{j}$ in the Upper Hore and Upper Hafren subcatchments, likely because organic horizons at Plynlimon have high concentrations of chemostatic solutes due large inputs of sea salts that dominate the chemical signature of near-surface pore waters. Provided this observation, organic associations in each catchment were 
evaluated by inspecting the ratio of average solute concentrations in the pore water versus precipitation (Fig. $4 b, c)$; i.e., precipitation serves as the most organic-poor pool in the Plynlimon system. For both the Upper Hafren and the Upper Hore, the ratios of concentrations in soil water versus precipitation were positively correlated with $m_{j}(p<0.05)$. Elements exhibiting enrichment behavior, including DOC, Al, $\mathrm{Mn}$, and $\mathrm{K}$ in both catchments plus Fe in the Upper Hafren, were also enriched in pore water relative to precipitation. Chemostatic elements in pore waters were less enriched relative to precipitation. In contrast, the ratios for soil water versus precipitation were not significantly correlated with $m_{j}$ at Shale Hills $(p>0.05)$.

\section{Discussion}

Cross-site comparison of the Shale Hills and Plynlimon headwater catchments revealed that the behaviors of nonchemostatic solutes were controlled by the spatial variability of those elements in soil waters and the distribution of DOC. Conversely, chemostatic solutes were homogeneously distributed in pore waters across the catchments. In the following sections, we discuss how the landscape distribution of chemically distinct pools and the connectivity between organic-rich soils and the stream control how concentrations vary with discharge. We contend that the behavior of certain elements are non-chemostatic in these systems due to their association with organic matter. The distribution of soil organic matter across landscapes is in turn influenced by climate (e.g., SOM generally increases with increasing moisture and decreasing temperatures on large geographic scales) and geomorphology (e.g., organic matter accumulates in depressed areas such as swales on small geographic scales).

\subsection{Hydrologic connectivity of solute pools across landscapes}

At first glance, it may appear contradictory that concentrations of non-chemostatic elements in the streams at Shale Hills and Plynlimon trend in opposite directions with increasing discharge; however, the discrepancy can be explained by differences in the distributions of organic-rich source waters in each system. Similar to bioactive elements identified by Stallard and Murphy (2013), we attribute nonchemostatic concentration-discharge behavior to changing water flow through organic-rich soil matrices; however, we also observe that organic-rich sources and flow paths vary between the catchments (Fig. 1).

At Shale Hills, meteoric water passes through the thin organic horizon and organic-rich A horizon $(<15 \mathrm{~cm}$ deep) and is transported along the horizon interfaces to the stream via preferential flow paths (Lin et al., 2006; Jin et al., 2011; Thomas et al., 2013). The stream receives water from organic-rich swales and surface soils during dry periods, and (a) Shale Hills
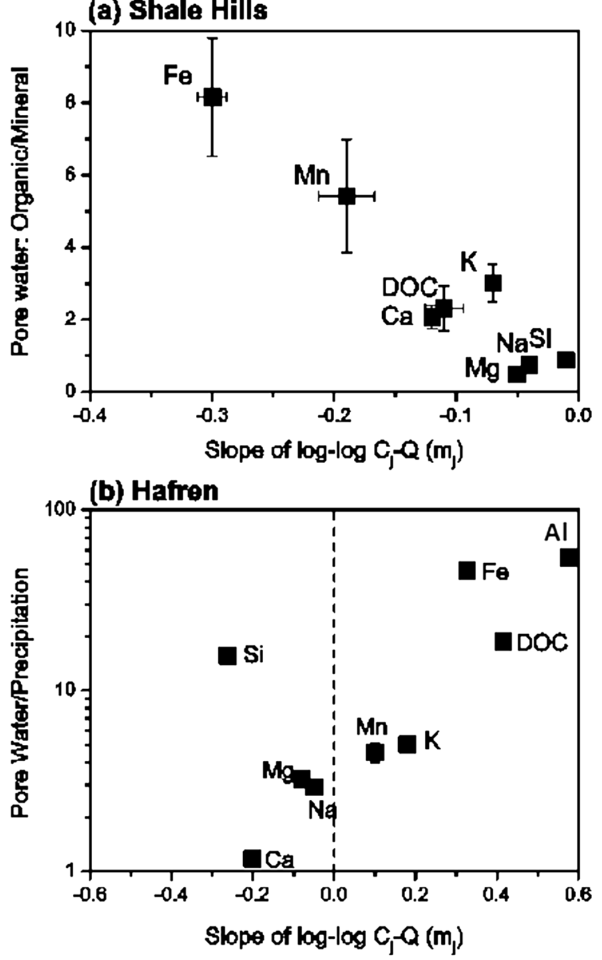

(c) Hore

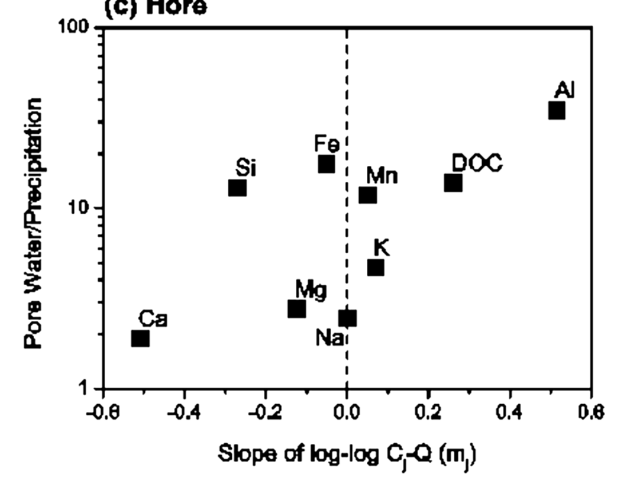

Figure 4. The degree of non-chemostatic behavior for a solute in stream water, denoted by $m_{j}$, was correlated with the relative concentration of that solute in organic-rich soil water in each catchment. Specifically, $m_{j}$ was (a) negatively correlated with the ratio of solute concentrations in organic-rich versus organic-poor soil waters at Shale Hills $\left(R^{2}=0.90, p<0.001\right)$ and positively correlated with the ratio of solute concentrations in pore waters versus precipitation in (b) the Upper Hafren $\left(R^{2}=0.48 ; p<0.05\right)$ and (c) the Upper Hore $\left(R^{2}=0.42 ; p<0.05\right)$. Error bars represent the standard error of each value and are smaller than the symbol where not visible.

water inputs from organic-poor hillslope soils increase as the catchment saturates (Qu and Duffy, 2007; Andrews et al., 2011). Consequently, we observed that stream water chemistry was similar to organic-rich soil waters at low flow and organic-poor soil waters at high flow (Fig. 3). Solutes derived largely from organic-rich soils exhibited greater variability 
over different flow regimes due to their high spatial variability in soil pore water. Increasingly negative slopes for nonchemostatic elements at high discharge (Fig. 2b) may reflect the transition in hydrologic connectivity and hillslope inputs to the stream. Stream chemistry did not reflect inputs from groundwater during dry periods, consistent with a previous finding that the water table drops to $>2 \mathrm{~m}$ below the stream bed during late summer (Thomas et al., 2013).

In the grass-dominated Upper Hafren, which contains peat soils that experience minimal water-rock interaction (Kirby et al., 1991), concentrations of chemostatic elements in the soils never deviated far from an average precipitation signal (Fig. 4). In contrast, concentrations of non-chemostatic elements were not driven by precipitation, and we propose that pore-water concentrations of these elements are regulated by vegetation. During the drier growing season, certain non-chemostatic elements may be depleted from soil pore water and accumulated in vegetation, leading to lower concentrations in the stream. Indeed, it is well established that seasonal uptake by vegetation regulates concentrations of nutrient elements in stream water (e.g., Johnson et al., 1969; Vitousek, 1977; Mulholland, 1992). Warming and drying of the surface peat during this time increases microbial decomposition, thereby increasing mobility of elements that accumulate in vegetation by releasing them from storage in organic matter (Kirby et al., 1991). According to this conceptual model, once transpiration decreases and flow increases through the soil in autumn, concentrations of these elements increase in the stream because (1) transpiration is reduced and the soil water is no longer being depleted, (2) the surface peat is flushed of elements that have accumulated, providing elements in addition to precipitation. As observed at the Upper Hafren and Upper Hore, concentrations of non-chemostatic elements begin to increase in the stream as discharge increases following low flow in the summer (Figs. S3 and S4). This effect may be especially prominent in the peat regions since the grass vegetation decomposes annually with little above-ground storage (i.e., peat is leaky with respect to nutrients), and anoxic conditions limit complete conversion of SOM to $\mathrm{CO}_{2}$, enhancing release of DOC. Although groundwater can discharge to streams in Plynlimon during summer months (Shand et al., 2005b), the groundwater contains little DOC (Table 3) and therefore cannot explain changes in summer stream chemistry where DOC increases from spring to summer (Figs. S3 and S4). At high flow, decreases in Mn concentrations in the stream (Fig. $2 \mathrm{~d}$ and g) may reflect the low abundance of $\mathrm{Mn}$ in the catchment relative to other elements; in other words, the supply of $\mathrm{Mn}$ is depleted at high flow and $\mathrm{Mn}$ is diluted in the stream.

In the spruce-forested Upper Hore, long-term storage of nutrient elements in above-ground biomass is expected to deplete soil pore waters of elements without the flushing effect due to rapid turnover observed in the Upper Hafren (Reynolds et al., 2000). Instead, the positive concentrationdischarge slopes in the Upper Hore result from flushing of upland peat soils at high-flow conditions (Neal et al., 1990). These effects can be observed by comparing preand post-harvest concentration-discharge slopes in the Upper Hore. Tree harvest impacted stream concentrations and $C-Q$ slopes for $\mathrm{K}, \mathrm{Al}, \mathrm{Fe}, \mathrm{Mn}$, and $\mathrm{DOC}$ but had no observable effects on chemostatic elements. Specifically, $m_{\mathrm{K}}$ increased from 0.07 to 0.25 following harvest, while the peatdominated Upper Hafren, which was not harvested, maintained $m_{\mathrm{K}}=0.15$ during this time. Fe and DOC experienced increases in stream concentrations, but not $m_{j}$. Since neither Fe nor DOC is expected to be taken up into the trees in high quantities, increasing $C_{j}$ may indicate that they were mobilized by increased decomposition of leaf litter debris in the forest region following harvest (Hughes et al., 1990).

Values of $C_{j}$ and $m_{j}$ for non-chemostatic, organicassociated elements likely increased following harvest because (1) these elements were no longer being taken up and stored in tree biomass (Stevens et al., 1997), (2) the organic debris left after harvest provided a labile pool of organic chelator molecules and organically complexed elements, and (3) inputs from upland peats to the stream increased due to lack of interception by the forest (Neal et al., 1992, 2004). Such short-term increases in nutrient loss following ecosystem disturbance are well documented, especially for clear-cut systems (e.g., Likens et al., 1970; Vitousek, 1977; Neal et al., 1992). Although non-chemostatic in the Upper Hafren, Fe followed a chemostatic trend in the Upper Hore (Fig. 2). This behavior could be due to $\mathrm{Fe}$ retention in the forested soils during downslope transport; Stagnopodzols on these slopes have Bs horizons that accumulate sesquioxides and immobilize leached Fe (Reynolds, 1982).

Previous studies have hypothesized that hydrologic connectivity within landscapes (McGlynn and McDonnell, 2003a; Hood et al., 2006; Clow and Mast 2010) and/or interactions between soil moisture and mineral reactive surface area (Godsey et al., 2009; Clow and Mast 2010) can explain concentration-discharge relationships across multiple catchments. Our results contribute to the understanding of solute behavior by highlighting the importance of hydrologic connectivity across landscapes and at mineral surfaces. At both Shale Hills and Plynlimon, the distribution of soil organic matter and its hydrologic connection to the stream governed non-chemostatic concentration discharge behavior of several solutes $(\mathrm{Ca}, \mathrm{K}, \mathrm{Mn}, \mathrm{Fe}$ and $\mathrm{Al})$, a process similarly invoked to explain stream DOC behavior in storm events (McGlynn and McDonnell, 2003b). Our results highlight the need to include or enhance reactive transport modules in spatially distributed watershed-scale hydrologic models such as TOPMODEL (Beven and Kirkby, 1979), the Penn State Integrated Hydrologic Model (PIHM; Qu and Duffy, 2007), and the Regional Hydro-Ecological Simulation System (RHESSys; Band et al., 1991). Specifically, combining reactive transport modeling (RTM) with the ability of spatially distributed models to simulate soil moisture, temperature, and water fluxes at variable depths across geomor- 
phic features (e.g., swales vs. planar slopes) will allow researchers to elucidate specific-flow water paths and transit times and better test drivers of chemostasis (cation exchange) and dynamics of mobile vs. immobile water. RT-Flux-PIHM (reactive transport flux - Penn State Integrated Hydrological Model) is one model under development (Duffy et al., 2014) that will provide this platform, but it is imperative to crosscompare outputs from various models in order to reach a consensus.

\subsection{Drivers of chemostasis}

Stream concentrations for most major weathering elements ( $j=\mathrm{Na}, \mathrm{K}, \mathrm{Mg}, \mathrm{Ca}, \mathrm{Si}$ ) varied little over a wide range of discharge values (Fig. 2); by this definition, most of the major elements were chemostatic, with the exception of $\mathrm{Ca}$ at Shale Hills and K at Plynlimon. Note that the standard descriptor "major elements" includes $\mathrm{Na}$ and $\mathrm{Ca}$ although both are low in abundance in the protolith at Shale Hills and Plynlimon ( $<0.7$ and $<0.2 \mathrm{wt} \%$, respectively), and $\mathrm{K}$ is lower at Plynlimon compared to Shale Hills (2.90 and 3.76 wt \%, respectively) (Jin et al., 2010; Dere et al., 2013). Chemostasis could be expected for elements derived from minerals that are always equilibrated with long residence-time pore waters. However, the fast-dissolving minerals present at Shale Hills and Plynlimon, carbonates and pyrite, do not contain $\mathrm{K}, \mathrm{Na}$, and $\mathrm{Si}$ and are also depleted in the upper protolith (Jin et al., 2010; Neal et al., 1997). Therefore, dissolution of these minerals cannot explain chemostasis of $\mathrm{K}, \mathrm{Na}, \mathrm{Si}$, $\mathrm{Mg}$, and Ca. Godsey et al. (2009) suggested that changes in mineral-water interfacial area during periods of high and low discharge explain chemostasis; however, clay dissolution rates are too slow (Bandstra et al., 2008) to provide a rapidly mobilized source of cations during the short timescales of precipitation events.

The exchangeable cation pool is a likely source of chemostatic elements during rain events (e.g., Clow and Mast, 2010). The cation exchange capacity of soils along the planar hillslope at Shale Hills ranges from 35 to 71 meq $\mathrm{kg}^{-1}$ (Jin et al., 2010). At Plynlimon, forest and peat soils have a cation exchange capacity of roughly 77.4 and 300 meq $\mathrm{kg}^{-1}$, respectively (Reynolds et al., 1988; Cuttle, 1983). Elements are displaced from cation exchange sites into solution by $\mathrm{H}^{+}$ (i.e., protonation of the exchange sites), and we observe that the degree of chemostasis for chemostatic elements was inversely related to the elements' relative strengths of adsorption to cation exchange sites as reported by Evangelous and Phillips (2005). Furthermore, this explanation can even account for the highly chemostatic, neutrally charged solute $\mathrm{Si}(\mathrm{OH})_{4}^{0}$, which has also been documented in the exchangeable pool at Shale Hills (Jin et al., 2010). For these catchments where $\mathrm{pH}$ is low $(\mathrm{pH}<7)$, Si should be weakly associated to exchange sites due to its neutral charge. The similar concentrations observed for major weathering elements in the planar and swale pore waters at Shale Hills as well as Plynlimon (Tables 2 and 3) are attributed to the quick exchange of protons in rain for cations in the exchange pool throughout the catchment. Thus, chemostasis is explained by increasing connectivity of the exchangeable pool, i.e., cations bound to surfaces of minerals and soil organic matter, to mobile water as soil saturation increases.

\subsection{Chemostatic nutrients become non-chemostatic under nutrient-limiting conditions}

Although geochemically similar to $\mathrm{Mg}, \mathrm{K}$, and $\mathrm{Na}$, the concentration-discharge pattern for $\mathrm{Ca}$ (Fig. 2) is nonchemostatic at Shale Hills. The mixing model (Fig. 3a) indicates leaves may be a primary source of $\mathrm{Ca}$ to the stream during low discharge. Indeed, these shallow soils are strongly leached of $\mathrm{Ca}(<0.16 \% \mathrm{wt}$; Jin et al., 2010), and organic matter may be a relatively large pool of Ca in this system. In contrast to Shale Hills where Ca trends are strongly influenced by organic matter, $\mathrm{Ca}$ at Plynlimon may be linked to groundwater, an effect most pronounced in the Upper Hore. Ratios of $\mathrm{Ca}: \mathrm{Mg}$ trend towards organic-poor sources at low flow, likely due to inputs of Ca-rich groundwater during base flow that is diluted by increasing contribution from soil water at high flow. Although a lack of groundwater data from these two subcatchments limits our ability to directly assess inputs to the stream, groundwater collected from lower elevations in the Plynlimon forest are rich in $\mathrm{Ca}$ and $\mathrm{Si}$ (Neal et al., 1997).

Similar to $\mathrm{Ca}$ at Shale Hills, $\mathrm{K}$ limitation may drive its increased association with organic matter at Plynlimon. Values of $C_{\mathrm{K}}: C_{\mathrm{Na}}$ decrease at Shale Hills and increase at Plynlimon with increasing $Q$ in a manner consistent with changing inputs from organic-rich sources (Fig. S6). Although geochemically similar, $\mathrm{Na}$ is a non-essential element (Kirkby, 2011) that is readily weathered from soils, whereas $K$ is a plant macronutrient that accumulates in leaf tissue (Herndon et al., 2015). From the mixing diagrams and $m_{\mathrm{K}}$, we infer that $\mathrm{K}$ has a stronger organic control at Plynlimon than at Shale Hills. One explanation for this is that net primary productivity (NPP) is higher $\left(896 \mathrm{~g} \mathrm{C} \mathrm{m}^{-2} \mathrm{yr}^{-1}\right.$; unpublished data) but bedrock K is lower (2.90 $\pm 0.13 \%$; Dere et al., 2013) at Plynlimon than at Shale Hills (NPP $=550 \mathrm{~g} \mathrm{C} \mathrm{m}^{-2} \mathrm{yr}^{-1}$; Smith, 2013 and $K=3.76 \pm 0.16 \%$; Jin et al., 2010). These data suggest that $\mathrm{K}$ is limiting to vegetation at Plynlimon while $\mathrm{Ca}$ is limiting to vegetation at Shale Hills due to high demand and low supply.

\section{Conclusions}

A comparison of three shale-derived catchments, the Shale Hills CZO (Critical Zone Observatory) in central Pennsylvania, USA, and the Upper Hafren and Upper Hore catchments in the Plynlimon forest, Wales, UK, reveals that the concentration-discharge behaviors of elements are strongly impacted by the distribution of organic matter in soils and 
the hydrologic connectivity of these soils to the stream. At Shale Hills, stream water is derived from organic-rich swales at low flow and then from both swale and planar hillslopes with increasing flow. At Plynlimon, stream water is only dominated by water from organic-rich soils at high flow, and contributions from organic-rich upland soils increased following lower elevation tree harvest in the Upper Hore catchment. Solutes that are limiting nutrients or that are strongly retained by vegetation exhibit non-chemostatic behavior in the stream because they are released to the stream along with dissolved organic carbon. This non-chemostatic behavior is opposite between Plynlimon and Shale Hills due to the different landscape distribution of organic-rich soils. Due to minimal redistribution by vegetation, $\mathrm{Na}, \mathrm{Mg}$, and $\mathrm{Si}$ are equally concentrated in pore fluids for organic-rich and organic-poor soils, and concentrations of these elements in stream water remain relatively constant. From this, we conclude that the transport of elements associated with organic matter, termed previously as organomarker elements (Hausrath et al., 2009), is strongly controlled by the movement of dissolved organic carbon, leading to a distinct non-chemostatic behavior in stream waters that contrasts with the chemostatic behavior of major weathering elements. Stream chemistry in headwater catchments are variable largely because of the chemical heterogeneities in distribution of organic-rich soils in catchments and how those soils connect to the stream.

\section{The Supplement related to this article is available online at doi:10.5194/hess-19-3333-2015-supplement.}

Author contributions. E. M. Herndon, P. L. Sullivan, and A. L. Dere analyzed the data. E. M. Herndon prepared the manuscript with contribution from all authors.

Acknowledgements. The authors thank Adam Wlostowski and two anonymous reviewers for helpful comments that improved the manuscript. This work was facilitated by NSF Critical Zone Observatory program grants to C. J. Duffy (EAR 07-25019) and S. L. Brantley (EAR 12-39285, EAR 13-31726). This research was conducted in Penn State's Stone Valley Forest, which is supported and managed by the Penn State Forestland Management Office in the College of Agricultural Sciences. Plynlimon data and support were provided by the Natural Environment Research Council Centre for Ecology and Hydrology (https://gateway.ceh.ac.uk/home). The authors acknowledge scientists who participated in sample collection and analysis, particularly L. Jin and D. Andrews. Special thanks to S. Grant for sample collection and D. Robinson, I. Robinson, S. Hughes, and B. Emmett for logistical support at Plynlimon. Additional support was provided by NSF grant EAR-10-52614 (to SLB), the Penn State Center for Global Studies, and the NSF GK-12 CarbonEARTH Grant (EHR-0947962).

Edited by: M. Weiler

\section{References}

Andrews, D. M., Lin, H., Zhu, Q., Jin, L., and Brantley, S. L.: Hot spots and hot moments of dissolved organic carbon export and soil organic carbon storage in the Shale Hills catchment, Vadose Zone J., 10, 943-954, 2011.

Band, L. E., Peterson, D. L., Running, S. W., Coughlan, J., Lammers, R., Dungan, J., and Nemani, R.: Forest ecosystem processes at the watershed scale: basis for distributed simulation, Ecol. Model., 56, 171-196, doi:10.1016/0304-3800(91)90199B, 1991.

Bandstra, J. Z., Buss, H. L., Campen, R. K., Liermann, L. J., Moore, J., Hausrath, E. M., Navarre-Sitchler, A. K., Jang, J., and Brantley, S. L.: Appendix: compilation of mineral dissolution rates, in: Kinetics of Water-Rock Interaction, edited by: Brantley, S.,Kubicki, J., and White, A., Springer, New York, 737-823, 2008.

Beven, K. J. and Kirkby, M. J.: A physically based variable contributing area model of basin hydrology, Hydrologic Science Bulletin, 24, 43-69, 1979.

Bishop, K., Siebert, J., Kohler, S., and Laudon, H.: Resolving the double paradox of rapidly mobilized old water with highly variable reponses in runoff chemistry, Hydrol. Process., 18, 185-189, 2004.

Brantley, S. L., Ketchum, B., White, T., and Sullivan, P. L.: Susquehanna Shale Hills Critical Zone Observatory Porewater Chemistry (2006), EarthChem, doi:10.2136/vzj2010.0133, 2013 a.

Brantley, S. L., Ravela, R., Jin, L., Nuester, J., and Sullivan, P. L.: Susquehanna Shale Hills Critical Zone Observatory Porewater Chemistry (2007), EarthChem, doi:10.2136/vzj2010.0133, 2013b.

Brantley, S. L., Jin, L., Andrews, D., Holmes, G., Holleran, M., Williams, J., Herndon, E., Sullivan, P. L.: Susquehanna Shale Hills Critical Zone Observatory Porewater Chemistry (2008), EarthChem, doi:10.1594/IEDA/100235, 2013c.

Brantley, S. L., Jin, L., Andrews, D., Holmes, G., Bhatt, M., Holleran, M., Kaiser, N., Williams, J., Herndon, E., Sullivan, P. L.: Susquehanna Shale Hills Critical Zone Observatory Porewater Chemistry (2009), EarthChem, doi:10.1594/IEDA/100236, 2013d.

Brantley, S. L., Bazilevskaya, E., Andrews, D., Williams, J., Herndon, E., Holmes, G., Bhatt, M., Holleran, M., Yesavage, T., Thomas, E., and Sullivan, P. L.: Susquehanna Shale Hills Critical Zone Observatory Porewater Chemistry (2010), EarthChem, doi:10.1594/IEDA/100237, 2013e.

Brantley, S. L., Ketchum, B., White, T., and Sullivan, P. L.: Susquehanna Shale Hills Critical Zone Observatory Stream Water Chemistry (2006), EarthChem, doi:10.1594/IEDA/100239, 2013e.

Brantley, S. L., Ravela, R., Jin, L., Nuester, J., and Sullivan, P. L.: Susquehanna Shale Hills Critical Zone Observatory Stream Water Chemistry (2007), EarthChem, doi:10.1594/IEDA/100240, $2013 f$.

Brantley, S. L., Jin, L., Andrews, D., Holmes, G., Holleran, M., Williams, J., Herndon, E., Duffy, C. J., and Sullivan, P. L.: Susquehanna Shale Hills Critical Zone Observatory Stream Water Chemistry (2008), EarthChem, doi:10.1594/IEDA/100241, $2013 \mathrm{~g}$.

Brantley, S. L., Jin, L., Andrews, D., Holmes, G., Bhatt, M., Holleran, M., Kaiser, N., Williams, J., Herndon, E., Duffy, 
C. J., and Sullivan, P. L.: Susquehanna Shale Hills Critical Zone Observatory Stream Water Chemistry (2009), EarthChem, doi:10.1594/IEDA/100242, 2013h.

Brantley, S. L., Bazilevskaya, E., Andrews, D., Williams, J., Herndon, E., Holmes, G., Bhatt, M., Holleran, M., Yesavage, T., Thomas, E., Duffy, C. J., and Sullivan, P. L.: Susquehanna Shale Hills Critical Zone Observatory Stream Water Chemistry (2010), EarthChem, doi:10.1594/IEDA/100243, 2013 i.

Brantley, S. L., Holleran, M. E., Jin, L., and Bazilevskaya, E.: Probing deep weathering in the Shale Hills Critical Zone Observatory, Pennsylvania (USA): the hypothesis of nested chemical reaction fronts in the subsurface, Earth Surf. Proc. Land., doi:10.1002/esp.3415, 2013j.

Brown, V. A., McDonnell, J. J., Burns, D. A., and Kendall, C.: The role of event water, a rapid shallow flow component, and catchment size in summer stormflow, J. Hydrol., 217, 171-190, 1999.

Clow, D. W. and Mast, M. A.: Mechanisms for chemostatic behavior in catchments: implications for $\mathrm{CO}_{2}$ consumption by mineral weathering, Chem. Geol., 269, 40-51, 2010.

Cuttle, S. P.: Chemical properties of upland peats influencing the retention of phosphate and potassium ions, J. Soil Sci., 34, 7582, 1983.

Dere, A. L., White, T. S., April, R. H., Reynolds, B., Miller, T. E., Knapp, E. P., McKay, L. D., and Brantley, S. L.: Climate dependence of feldspar weathering along a latitudinal gradient, Geochim. Cosmochim. Ac., 122, 101-126, 2013.

Duffy, C.: Stream flow data, available at: http://www.czo.psu.edu (last access: 17 January 2012), 2012.

Duffy, C., Shi, Y., Davis, K., Slingerland, R., Li, L., Sullivan, P. L., and Brantley, S. L.: Designing a Suite of Models to Explore Critical Zone Function, Procedia Earth and Planetary Science, 10, 7-15, doi:10.1016/j.proeps.2014.08.003, 2014.

Evangelous, V. P. and Phillips, R. E.: Cation Exchange in Soils, in SSSA Book Series, Chemical Processes in Soils, 8, edited by: Tabatabai, M. A. and Sparks, D. L., 343-410, 2005.

Fisher, S. G., Sponseller, R. A., and Heffernan, J. B.: Horizons in stream biogeochemistry: flowpaths to progress, Ecology, 85, 2369-2379, 2004.

Gaillardet, J., Dupré, B., Louvat, P., and Allegre, C. J.: Global silicate weathering and $\mathrm{CO}_{2}$ consumption rates deduced from the chemistry of large rivers, Chem. Geol., 159, 3-30, 1999.

Godsey, S. E., Kirchner, J. W., and Clow, D. W.: Concentrationdischarge relstionships reflect chemostatic charateristics of US catchements, Hydrol. Process., 23, 1844-1864, doi:10.1002/hyp.7315, 2009.

Haria, A. H. and Shand, P.: Evidence for deep sub-surface flow routing in forested upland Wales: implications for contaminant transport and stream flow generation, Hydrol. Earth Syst. Sci., 8, 334-344, doi:10.5194/hess-8-334-2004, 2004.

Hausrath, E. M., Neaman, A., and Brantley, S. L.: Elemental release rates from dissolving basalt and granite with and without organic ligands, Am. J. Sci., 309, 633-660, 2009.

Herndon, E. M., Jin, L., Andrews, D. M., Eissenstat, D. M., and Brantley, S. L.: Importance of vegetation for manganese cycling in temperate forested watersheds, Global Biogeochem. Cy., 29, $160-174,2015$.

Hood, E., Gooseff, M. N., and Johnson, S.: Changes in the character of stream water dissolved organic carbon during flush- ing in three small watersheds, Oregon, J. Geophys. Res., 111, doi:10.1029/2005JG000082, 2006.

Hughes, S., Reynolds, B., and Roberts, J. D.: The influence of land management on concentrations of dissolved organic carbon and its effects on the mobilization of aluminium and iron in podzol soils in Mid-Wales, Soil Use Manage., 6, 137-145, 1990.

Jin, L., Ravella, R., Ketchum, K., Bierman, P. R., Heaney, P., White, T., Brantley, S. L.: Mineral weathering and elemental transport during hillslope evolution at the Susuehanna/Shale Hills Critical Zone Observatory, Geochim. Cosmochim. Ac., 74, 3669-3691, 2010.

Jin, L., Andrews, D. M., Holmes, G. H., Lin, H., and Brantley, S. L.: Opening the "Black Box": water chemistry reveals hydrological controls on weathering in the Susquehanna Shale Hills Critical Zone Observatory, Vadose Zone J., 10, 928-942, doi:10.2136/vzj2010.0133, 2011.

Johnson, N. M., Likens, G. E., Bormann, F. H., Fisher, D. W., and Pierce, R. S.: A working model for the varation in stream water chemistry at the Hubbard Brook Experimental Forest, New Hampshire, Water Resour. Res., 5, 1353-1363, 1969.

Kirby, C., Newson, M. D., and Gilman, K.: Plynlimon Research: The first two decades, Institute of Hydrology, Wallingford, UK, Report No. 109, 1991.

Kirkby, E.: Introduction, definition, and classification of nutrients, in: Marschner's Mineral Nutrition of Higher Plants, edited by: P. Marschner, Academic Press, Elsevier, doi:10.1016/B978-0-12384905-2.00001-7, 2011.

Kirchner, J. W.: A double paradox in catchment hydrology and geochemistry, Hydrol. Process., 17, 872-874, 2003.

Köhler, S. J., Lidman, F., and Laudon, H.: Landscape types and pH control organic matter mediated mobilization of $\mathrm{Al}, \mathrm{Fe}, \mathrm{U}$ and $\mathrm{La}$ in boreal catchments, Geochim. Cosmochim. Ac., 135, 190-202, 2014.

Krám, P., Hruška, J., Wenner, B. S., Driscoll, C. T., and Johnson, C. E.: The biogeochemistry of basic cations in two forest catchments with contrasting lithology in the Czech Republic, Biogeochemistry, 37, 173-202, 1997.

Likens, G. E. and Buso, D. C.: Variation in streamwater chemistry throughout the Hubbard Brook Valley, Biogeochemistry, 78, 130, 2006

Likens, G. E., Bormann, F. H., Johnson, N. M., Fisher, D. W., and Pierce, R. S.: Effects of forest cutting and herbicide treatment on nutrient budgets in the Hubbard Brook watershed-ecosystem, Ecol. Monog., 40, 23-47, 1970.

Lin, H.: Temporal stability of soil moisture spatial patterns and subsurface preferential flow pathways in the Shale Hills catchment Vadose Zone J., 5, 317-340, doi:10.2136/vzj2005.0058, 2006.

Lin, H. S., Kogelmann, W., Walker, C., and Bruns, M. A.: Soil moisture patterns in a forested catchment: A hydropedological perspective, Geoderma, 131, 345-368, doi:10.1016/j.geoderma.2005.03.013, 2006.

Maher, K.: The role of fluid residence time and topographic scales in determining chemical fluxes from landscapes, Earth Planet. Sc. Lett., 312, 48-58, 2011.

McClain, M. E., Boyer, E. W., Dent, C. L., Gergel, S. E., Grimm, N. B., Groffman, P. M., Hart, S. C., Harvey, J. W., Johnston, C. A., Mayorga, E., McDowell, W. H., and Pinay, G.: Biogeochemical hot spots and hot moments at the interface of terrestrial and aquatic ecosystems, Ecosystems, 6, 301-312, 2003. 
McGlynn, B. L. and McDonnell, J. J.: Role of discrete landscape units in controlling catchment dissolved organic carbon dynamics, Water Resour. Res., 39, 1090-1108, doi:10.1029/2002WR001525, 2003a.

McGlynn, B. L. and McDonnell, J. J.: Quantifying the relative contributions of riparian and hillslope zones to catchment runoff, Water Resour. Res., 39, 1310-1330, doi:10.1029/2003WR002091, 2003b.

Mulholland, P. J.: Regulation of nutrient concentrations in a temperate forest stream: roles of upland, riparian, and instream processes, Limnol. Oceanogr., 37, 1512-152, 1992.

National Atmospheric Deposition Program (NRSP-3), NADP Program Office, Illinois State Water Survey, available at: http://nadp. sws.uiuc.edu/ (last access: 5 December 2011), 2011.

Neal, C. and Kirchner, J. W.: Sodium and chloride levels in rainfall, mist, streamwater and groundwater at the Plynlimon catchments, mid-Wales: inferences on hydrological and chemical controls, Hydrol. Earth Syst. Sci., 4, 295-310, doi:10.5194/hess-4295-2000, 2000.

Neal, C., Smith, C. J., Walls, J., Billingham, P., Hill, S., and Neal, M.: Hydrogeochemical variations in Upper Hafren forest stream waters, mid-Wales, J. Hydrol., 116, 185-200, 1990.

Neal, C., Fisher, R., Smith, C. J., Hill, S., Neal, M., Conway, T., Ryland, G. P., and Jeffrey, H. A.:. The effects of tree harvesting on stream-water quality at an acidic and acid-sensitive spruce forested area: Plynlimon, mid-Wales, J. Hydrol., 135, 305-319, 1992.

Neal, C., Robson, A. J., Shand, P., Edmunds, W. M., Dixon, A. J., Buckley, D. K., Hill, S., Harrow, M., Neal, M., Wilkinson, J., and Reynolds, B.: The occurrence of groundwater in the Lower Palaeozoic rocks of upland Central Wales, Hydrol. Earth Syst. Sci., 1, 3-18, doi:10.5194/hess-1-3-1997, 1997.

Neal, C., Reynolds, B., Neal, M., Wickham, H., Hill, L., and Williams, B.: The impact of conifer harvesting on stream water quality: the Afon Hafren, mid-Wales, Hydrol. Earth Syst. Sci., 8, 503-520, doi:10.5194/hess-8-503-2004, 2004.

Neal, C., Robinson, M., Reynolds, B., Neal, M., Rowland, P., Grant, S., Norris, D., Williams, B., Sleep, D., and Lawlor, A.: Hydrology and water quality of the headwaters of the River Severn: Stream acidity recovery and interactions with plantation forestry under an improving pollution climate, Sci. Total Environ., 408, 5035-5051, 2010.

Neal, C., Reynolds, B., Norris, D., Kirchner, J. W., Neal, M., Rowland, P., Wickham, H., Harman, S., Armstrong, L., Sleep, D., Lawlor, A., Woods, C., Williams, B., Fry, M., Newton, G., and Wright, D.: Three decades of water quality measurements from the Upper Severn experimental catchments at Plynlimon, Wales: and openly accessible data resource for research, modelling, environmental management and education, Hydrol. Process., 25, 3818-3830, doi:10.1002/hyp.8191, 2011.

Neal, C., Reynolds, B., Rowland, P., Norris, D., Kirchner, J. W., Neal, M., Sleep, D., Lawlor, A., Woods, C., Thacker, S., Guyatt, H., Vincent, C., Hockenhull, K., Wickham, H., Harman, S., and Armstrong, L.: High-frequencey water quality time series in precipitation and streamflow: From fragmentary signals to scientific challenge, Sci. Total Environ., 434, 3-12, 2012.

Neal, C., Kirchner, J., and Reynolds, B.: Plynlimon research catchment hydrochemistry, NERC-Environmental Information Data
Centre, doi:10.5285/44095e17-43b0-45d4-a781-aab4f72da025, 2013a.

Neal, C., Kirchner, J., and Reynolds, B.: Plynlimon research catchment high-frequency hydrochemistry data, NERC-Environmental Information Data Centre, doi:10.5285/551A10ae-b8ed-4ebd-ab38-033dd597a374, 2013b.

Pringle, C. M.: Hydrologic connectivity and the management of biological reserves: a global perspective, Ecol. Appl., 11, 981-998, 2001.

Qu, Y. and Duffy, C. J.: A semidiscrete finite volume formulation for multiprocess watershed simulation, Water Resour. Res., 43, doi:10.1029/2006WR005752, 2007.

Reynolds, B.: Preliminary studies on the laboratory simulation of nutrient transfers within a podzol soil, Bangor Occasional Paper No. 12, Bangor, UK, 1982.

Reynolds, B., Hornung, M. and Stevens, P. A.: Solute budgets and denudation rate estimates for a mid-Wales catchment, Catena, 14, 13-23, 1987.

Reynolds, B., Neal, C., Hornung, M., Hughes, S., and Stevens, P. A.: Impact of afforestation on the soil solution chemistry of stagnopodzols in mid-Wales, Water Air Soil Poll., 38, 55-70, 1988.

Reynolds, B., Wood, M. J., Truscott, A. M., Brittain, S. A., and Williams, D. L.: Cycling of nutrient base cations in a twelve year old Sitka spruce plantation in upland mid-Wales, Hydrol. Earth Syst. Sci., 4, 311-321, doi:10.5194/hess-4-311-2000, 2000.

Rudeforth, C. C., Hartnup, R., Lea, J. W., Thompson, T. R. E., and Wright, P. S.: Soils and their use in Wales, Soil Survey of England and Wales Bulletin No. 11, Harpenden, UK, 336 pp., 1984.

Shand, P., Abesser, C., Farr, G., Wilton, N., Lapworth, D. J., Gooddy, D. C., Haria, A., and Hargreaves, R.: Baseline report series: 17, The Ordovician and Silurian meta-sedimentary aquifers of central and south-west Wales, British Geological Survey, Commissioned Report CR/05/034N, Environment Agency National Groundwater \& Contaminated Land Centre, Technical Report NC/99/74/17, 2005a.

Shand, P., Haria, A. H., Neal, C., Griffiths, K. J., Gooddy, D. C., Dixon, A. J., Hill, T., Buckley, D. K., and Cunningham, J. E.: Hydrochemical heterogeneity in an upland catchment: further characterisation of the spatial, temporal and depth variations in soils, streams and groundwaters of the Plynlimon forested catchment, Wales, Hydrol. Earth Syst. Sci., 9, 621-644, doi:10.5194/hess-9621-2005, 2005b.

Shand, P., Darbyshire, D. P. F., Gooddy, D., and Haria, A.: ${ }^{87} \mathrm{Sr} /{ }^{86} \mathrm{Sr}$ as an indicator of flowpaths and weathering rates in the Plynlimon experimental catchments, Wales, UK, Chem. Geol., 236, 247-265, 2007.

Shand, P., Darbyshire, D. P. F., Love, A. J., and Edmunds, W. M.: Sr isotopes in natural waters: Applications to source characterization and water-rock interaction in contrasting landscapes, Appl. Geochem., 24, 574-586, 2009.

Smith, L. A.: Aboveground carbon distribution across a temperate watershed, MS Thesis, The Pennsylvania State University, Pennsylvania, USA, 2013.

Sivapalan, M.: Pattern, process and function: elements of a unified theory of hydrology at the catchment scale, in: Encyclopedia of Hydrological Sciences, edited by: Anderson, M. G., John Wiley \& Sons Inc., Chichester, UK, 193-220, 2005. 
Stallard, R. F., and Murphy, S. F.: A unified assessment of hydrologic and biogeochemical responses in research watersheds in eastern Puerto Rico using runoff-concentration relations, Aquat. Geochem., 20, 115-139, 2013.

Stevens, P. A., Reynolds, B., Hughes, S., Norris, D. A., and Dickinson, A. L.: Relationships between spruce plantation age, solute and soil chemistry in Hafren forest, Hydrol. Earth Syst. Sci., 1, 627-637, doi:10.5194/hess-1-627-1997, 1997.

Takagi, K. and Lin, H. S.: Changing controls of soil moisture spatial organization in the Shale Hills Catchment, Geoderma, 173, 289$302,2012$.
Thomas, E. M., Lin, H., Duffy, C. J., Sullivan, P. L., Holmes, G. H., Brantley, S. L., and Jin, L.: Spatiotemporal patterns of water stable isotope compositions at the Shale Hills Critical Zone Observatory: Linkages to subsurface hydrologic processes, Vadose Zone J., 12, doi:10.2136/vzj2013.01.0029, 2013.

Vitousek, P. M.: The regulation of element concentrations in mountain streams in the northeastern United States, Ecol. Monogr., 47, 65-87, 1977.

Zimmer, M. A., Bailey, S. W., McGuire, K. J., and Bullen, T. D.: Fine scale variations of surface water chemistry in ephemeral and perennial drainage networks, Hydrol. Process., 27, 3438-2451, doi:10.1002/hyp.9449, 2012. 